Sains Malaysiana 51(2)(2022): 619-632

http://dx.doi.org/10.17576/jsm-2022-5102-25

\title{
Bödewadt Flow and Heat Transfer in Nanofluid over a Permeable and Radially Stretching Disk
}

(Aliran Bödewadt dan Pemindahan Haba dalam Nanobendalir terhadap Cakera Telap dan Meregang secara Jejarian)

\author{
ANIS ANISAH MAHYUDDIN, LOK YIAN YIAN* \& SYAKILA AHMAD
}

\begin{abstract}
A Bödewadt boundary layer flow and heat transfer problem in nanofluid was investigated in this study for suction/ injection as well as combined effects of suction/injection and radial stretching disk. Similarity variables were introduced to transform the three-dimensional flow into a system of ordinary differential equations. Moreover, similar to the Bödewadt heat transfer problem in a viscous fluid, adequate suction is also required so that similarity solutions exist for nanofluid problems with no other boundary effects such as a partial slip or stretching disk. Both the suction and stretching disk effects can suppress the natural oscillatory behavior of flow apart from reducing the momentum and thermal boundary layer thicknesses. As expected, injection acts oppositely. However, the skin friction coefficient and heat transfer rate for Bödewadt flow increase with the increasing suction and stretching parameters. As for stagnant disk, increasing the nanoparticle volume fraction can enhance the wall shear stress, whereas nanofluid can only enhance the heat transfer when both the suction and nanoparticle volume fraction are sufficiently small. For radially stretching disk, both the local skin friction coefficient and local Nusselt number increase as the nanoparticle volume fraction increases. However, for larger suction, a smaller volume fraction of nanoparticles yielded enhanced heat transfer than the larger volume fraction of nanoparticles.
\end{abstract}

Keywords: Bödewadt flow; nanofluid; numerical solutions; radial stretching; suction/injection

ABSTRAK

Penyelidikan ini mengkaji masalah aliran sempadan Bödewadt dan pemindahan haba dalam nanobendalir bagi kes sedutan/semburan dan juga gabungan kes sedutan/semburan dan regangan jejari cakera. Pemboleh ubah keserupaan telah diperkenalkan untuk menjelmakan aliran tiga dimensi kepada sistem persamaan pembezaan biasa. Sama seperti kes pemindahan haba Bödewadt dalam cecair likat, tenaga sedutan yang mencukupi juga diperlukan agar penyelesaian keserupaan wujud untuk masalah nanobendalir tanpa kesan sempadan lain seperti slip separa atau regangan cakera. Kedua-dua kes sedutan dan regangan mempunyai kesan untuk menekan perilaku aliran berayun semula jadi dan dapat mengurangkan ketebalan lapisan sempadan momentum dan termal. Seperti yang dijangkakan, semburan bertindak sebaliknya. Pekali geseran kulit dan kadar pemindahan haba untuk aliran Bödewadt meningkat dengan peningkatan parameter penyedutan dan regangan. Untuk kes cakera statikyang tiada regangan tetapi berlakunya sedutan, peningkatan pecahan isi padu nanozarah meningkatkan geseran dinding. Walau bagaimanapun, peningkatan pemindahan haba hanya berlaku ketika nilai sedutan dan pecahan isi padu nanozarah cukup kecil. Untuk kes cakera regangan jejari, kedua-dua parameter iaitu pekali geseran kulit tempatan dan nombor Nusselt tempatan meningkat apabila pecahan isi padu nanozarah meningkat. Namun, untuk nilai sedutan yang besar, pecahan isi padu nanozarah yang lebih kecil memberikan peningkatan pemindahan haba yang lebih baik daripada pecahan isi padu nanozarah yang lebih besar.

Kata kunci: Aliran Bödewadt; nanobendalir; penyelesaian berangka; regangan jejari; sedutan/semburan

\section{INTRODUCTION}

Bödewadt flow which is named after Bödewadt refers to a three-dimensional flow due to the rotating fluid with a uniform angular velocity far from a stationary disk. Due to friction at the thin layer near the surface disk, the secondary flow is directed radially inwards and axially upwards (Schlichting 1979). A solution to Bödewadt flow was obtained by Bödewadt in 1940 using the transformation similar to that of Von Karman's in 1921 who solved the swirling flow induced by a rotating disk. However, the 
Bödewadt flow is reverse to that of the Von Karman flow. Von Karman flow velocity moves toward the rotating disk, while the axial velocity component is directed away from the stationary disk for the Bödewadt flow. Also, Bödewadt's boundary layer flow involves three velocity components exhibiting a more complex flow and a thicker boundary layer compared to Von Karman's boundary layer flow (Rahman \& Andersson 2017).

In 1951, Batchelor suggested a large Reynolds number for the rotor-stator flow to produce two shear layers between a rotating disk and a stationary disk. When this boundary layer is separated, the radial outflow close to the rotating disk is identified as Von Karman flow, while the radial inflow close to the stationary disk is Bödewadt flow (Batchelor 1951). Since then, many experiments and analyses were conducted to study the stability of Bödewadt flow (Faller 1991; Fernandez-Feria 2002; Lingwood \& Alfredsson 2000; Lopez \& Weidman 1996; MacKerrell 2005; Savaş 1987). Recently, Sahoo et al. (2014) obtained numerical solutions for the Bödewadt flow in a viscous fluid with partial slip condition using two different methods, namely the finite difference and Keller-box methods. They also showed that the slip has a prominent effect in reducing the axial velocity and pressure of the flow. Besides that, increasing the slip will decrease the torque required to maintain the disk at rest. Moreover, Rahman and Andersson (2018) presented their study on the Bödewadt flow of a fluid-particle suspension with strong suction. They reported that the fluid motion was reduced due to particle-fluid interaction. Meanwhile, Turner and Weidman (2017) documented that a suitably large stretching rate can control the instability growth in the boundary layer of Bödewadt flow in a viscous fluid. Similar behavior was also observed for shrinking disk except that shrinking disk profiles are more unstable than that of the stretching disk. More recently, Rafiq and Hashmi (2019) studied the Bödewadt flow in viscous fluid with large wall suction and chemical reaction. Their study indicated that the concentrations at the wall vary substantially if the rates of chemical reactions were increased.

On the other hand, Sahoo and Poncet (2012) investigated Bödewadt flow in non-Newtonian fluids where they studied the effects of partial slip on steady Bödewadt in visco-inelastic fluid, namely the ReinerRivlin fluid. Their problem was also extended to assess the effects of uniform suction or injection together with partial slip conditions by Sahoo et al. (2015). They showed that suction could significantly decrease the boundary layer thickness, while the opposite effects were observed for the case of injection.
The above-mentioned studies investigated the Bödewadt flow problems in Newtonian and nonNewtonian fluids. Whereas, several studies focused on Bödewadt heat transfer problems. Sahoo (2011) studied the effects of partial slip on the heat transfer analysis of Bödewadt flow of an electrically conducting ReinerRivlin fluid. Before Sahoo introduced the effect of partial slip on heat transfer analysis, the case of no-slip condition studied by Sahoo et al. (2012) showed the effects of non-slip condition on flow and heat transfer characteristics in Bödewadt flow. Furthermore, Turkyilmazoglu (2015) investigated the Bödewadt heat transfer problem over a uniformly stretched stationary disk with uniform temperature in a viscous fluid. Rahman and Andersson (2017) presented a similarity solution of Bödewadt thermal flow in the presence of suction. Mustafa et al. (2018) obtained the similarity solution for radiative heat transfer in Bödewadt slip flow subject to strong wall suction. Recently, Rafiq et al. (2019) studied the impacts of variable fluid properties on Bödewadt heat transfer problem with suction. They demonstrated that the inclusion of wall suction could lead to the thinning of boundary layer thickness, whereby the employment of thermal viscosity can lower the wall shear stress, while increment in thermal conductivity can deteriorate the heat transfer rate. Besides that, Sahoo and Shevchuk (2019) considered the Bödewadt heat transfer of Reiner-Rivlin fluid over a stretchable surface with variation in power-law temperature. It was determined that the increase in the stretching rate could also increase the rate of heat transfer.

According to several studies (Mustafa et al. 2018; Rafiq et al. 2019; Rahman \& Andersson 2017), increasing the suction can reduce the thickness of the boundary layer to control the flow. This observation is reasonable because Bödewadt flow occurs radially inwards and axially upwards near the stationary disk, therefore sufficient suction is needed so that the direction of the axial flow can be reversed. Meanwhile, Rahman and Andersson (2017) pointed out that suction plays an important role in thermal Bödewadt flow with the no-slip condition. They claimed that the heat transfer results presented by Sahoo et al. (2012) (for Reiner-Rivlin fluid without noslip condition and suction) and Turkyilmazoglu (2015) (for viscous fluid without stretching and suction) were questionable, therefore these problems were revisited. Their findings showed that the 'realistic similarity solutions of the thermal energy problem do not exist for Bödewadt flow is in the absence of suction' (Rahman \& Andersson 2017). This conclusion is only applicable to 'pure' stationary disk and does not apply to other 
boundary effects such as a partial slip or stretching disk. Having said that, stretching disk plays the same role as suction to increase the heat transfer and to reduce the boundary layer thickness. Importantly, studies by Sahoo and Shevchuk (2019) and Turkyilmazoglu (2015) demonstrated that both the momentum and thermal boundary layer thicknesses can be reduced even for moderate strength of stretching.

Bödewadt flow applications can be found in the industries, such as rotating machinery and mixing of chemicals in chemical engineering. Recently, nanofluids emerged as important industrial fluids used to enhance heat transfer. Hence, many classical Newtonian fluid problems were re-examined to study the effects of nanoparticles on the flow and heat transfer characteristics. Presently, there are limited studies of Bödewadt flow in nanofluids. Mustafa et al. (2015) and Khan et al. (2017) studied the Bödewadt flow and heat transfer problem over a radially stretching disk by formulating the problem using Tiwari \& Das model and Buongiorno model, respectively. Both the models solved the problem using the Keller-box method. They showed that increasing the nanoparticle volume fraction can enhance both the skin friction coefficient and heat transfer rate. Next, Joshi et al. (2017) studied the Bödewadt flow of a ferrofluid in the presence of geothermal viscosity. The problem was solved using the fourth-order Runge-Kutta method and shooting technique. The study also showed that heat transfer could be enhanced by increasing the fluid's porosity and rotation.

In this study, the problem of boundary layer flow and heat transfer of steady revolving Bödewadt flow in nanofluid was studied. The effects of stretching disk in the presence of suction or injection were investigated. This study adopted the Tiwari \& Das model for the nanofluids where the base fluid is water and the nanoparticles were either copper $(\mathrm{Cu})$ or silver $(\mathrm{Ag})$. Copper and silver are metals with excellent conductor and heat transfer. The physical properties of copper such as strength, corrosion resistance and ductility make copper suitable for wide range of application in engineering. Silver nanoparticles are being used as antibacterial agents where its applications can be found in wound treatment, water purification and waste management. The governing equations of Bödewadt flow were transformed into nonlinear differential equations using the similarity variables similar to that of the conventional Von Karman flow and were numerically solved using the Keller-box method. Meanwhile, the effects of important governing parameters on the velocity, temperature and nanoparticle volume fraction profiles were also investigated. The discussion of this study is separated into two parts. The first part of the study investigated the effects of suction or injection on the Bödewadt flow and heat transfer problem over a stationary disk. While the second part assessed the effects of suction/injection on the problem over a stretchable disk. The results are expected to better understand the flow and heat transfer characteristics of Bödewadt flow in nanofluids. It has to be mentioned here that the process of heat transfer in nanofluid can be accelerates with the imposition of suction parameter while injection parameter acts in opposite manners. Hence, suction/injection is useful in tackling the mass transfer cooling system.

\section{MATHEMATICAL FORMULATION}

Figure 1 illustrates the schematic diagram in cylindrical coordinates $(r, \varphi, z)$ for the steady rotating flow of the nanofluid over a stretchable and permeable stationary disk. The circular disk located at $z=0$ with constant temperature $\left(T_{w}\right)$ can be stretched uniformly in the radial direction with a stretching rate $(c)$. Since the disk is permeable, $w_{0}$ is the velocity of wall transpiration. It is assumed that the fluid rotates with a constant angular velocity of $\Omega$ at a substantial distance from the stationary disk. The rotating flow was maintained at a constant temperature $\left(T_{\infty}\right)$ and far-field pressure $\left(P_{\infty}\right)$, far from the wall. This study considered two types of nanofluids. The base fluid is water $(\operatorname{Pr}=6.2)$ while the nanoparticles under study include $\mathrm{Cu}$ and $\mathrm{Ag}$. The thermophysical properties of the base fluid and nanoparticles are provided in Table 1. Meanwhile, the derivative along the tangential coordinate $(\varphi)$ can be neglected due to the rotation about the $z$-axis, $\partial / \partial \varphi=0$. Due to the symmetry flow on the $z$-axis, the pressure of the fluid depended only on the radial and axial coordinates, $p=p(r, z)$. Hence, the governing equations of continuity, momentum and energy are (Mustafa et al. 2015; Rahman \& Andersson 2017):

$$
\begin{aligned}
& \frac{\partial u}{\partial r}+\frac{u}{r}+\frac{\partial w}{\partial z}=0 \\
& \rho_{n f}\left(u \frac{\partial u}{\partial r}-\frac{v^{2}}{r}+w \frac{\partial u}{\partial z}\right)=-\frac{\partial p}{\partial r}+\mu_{n f}\left(\frac{\partial^{2} u}{\partial r^{2}}+\frac{1}{r} \frac{\partial u}{\partial r}-\frac{u}{r^{2}}+\frac{\partial^{2} u}{\partial z^{2}}\right) \\
& \rho_{n f}\left(u \frac{\partial v}{\partial r}+\frac{u v}{r}+w \frac{\partial v}{\partial z}\right)=\mu_{n f}\left(\frac{\partial^{2} v}{\partial r^{2}}+\frac{1}{r} \frac{\partial v}{\partial r}-\frac{v}{r^{2}}+\frac{\partial^{2} v}{\partial z^{2}}\right) \\
& \rho_{n f}\left(u \frac{\partial w}{\partial r}+w \frac{\partial w}{\partial z}\right)=-\frac{\partial p}{\partial z}+\mu_{n f}\left(\frac{\partial^{2} w}{\partial r^{2}}+\frac{1}{r} \frac{\partial w}{\partial r}+\frac{\partial^{2} w}{\partial z^{2}}\right) \\
& \left(\rho C_{p}\right)_{n f}\left(u \frac{\partial T}{\partial r}+w \frac{\partial T}{\partial z}\right)=k_{n f}\left(\frac{\partial^{2} T}{\partial r^{2}}+\frac{1}{r} \frac{\partial T}{\partial r}+\frac{\partial^{2} T}{\partial z^{2}}\right)
\end{aligned}
$$


subject to the boundary conditions:

$$
\begin{aligned}
& u=c r, \quad v=0, \quad w=-w_{0}, \quad T=T_{w} \text { at } \quad z=0, \\
& u \rightarrow 0, \quad v \rightarrow r \Omega, \quad T \rightarrow T_{\infty}, \quad \text { as } \quad z \rightarrow \infty,
\end{aligned}
$$

where $(u, v, w)$ are the velocity components of the fluid in the radial, tangential and axial directions, respectively, $T$ is the temperature of nanofluid, $p$ is pressure, $\rho_{n f}$ is the density of nanofluid, $\mu_{n f}$ is the dynamic viscosity of nanofluid, $\left(C_{p}\right)_{n f}$ is the specific heat of nanofluid at constant pressure, $k_{n f}$ is the thermal conductivity of nanofluid and $w_{0}>0$ for suction case while $w_{0}<0$ for injection case.

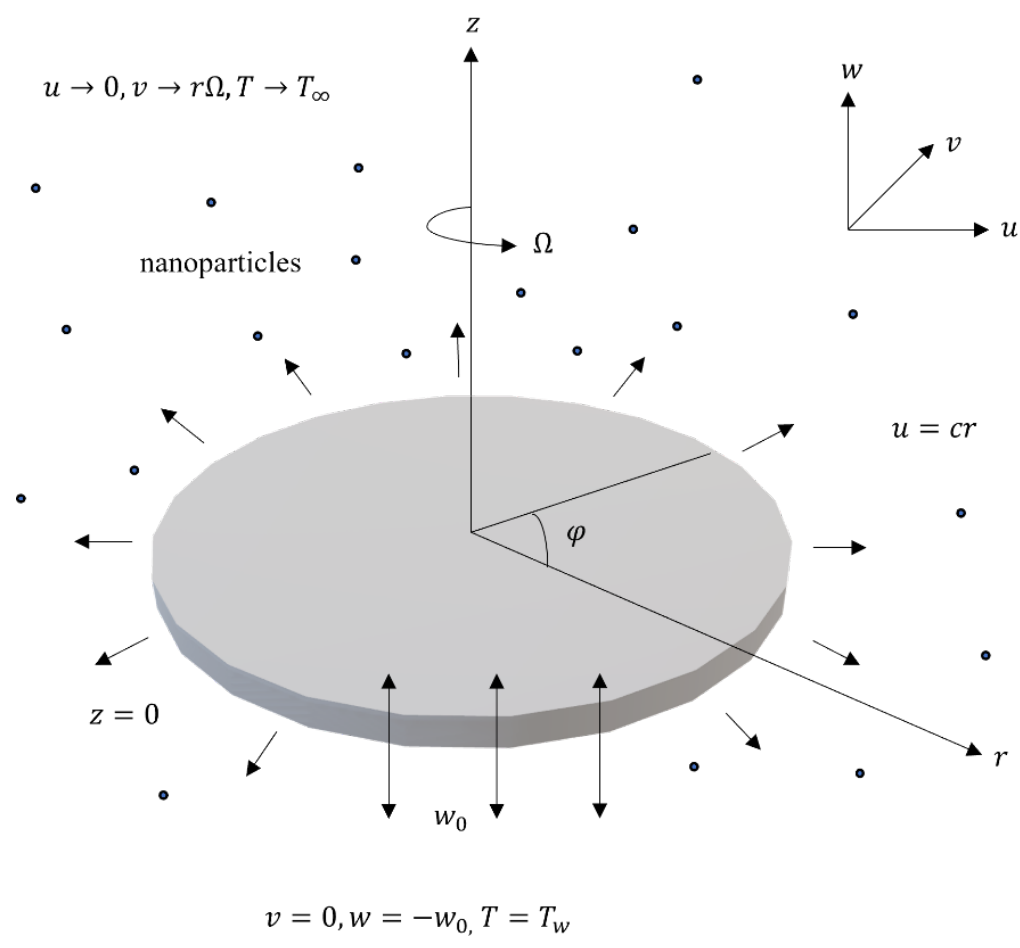

FIGURE 1. Physical model and coordinates system

TABLE 1. Thermophysical properties of the base fluid and nanoparticles (Cengel 2004)

\begin{tabular}{lccc}
\hline \multirow{2}{*}{ Properties } & Base fluid & \multicolumn{2}{c}{ Nanoparticles } \\
\cline { 2 - 4 } & Water & $\mathrm{Cu}$ & $\mathrm{Ag}$ \\
\hline Thermal conductivity, $k(\mathrm{~W} / \mathrm{mK})$ & 0.613 & 401 & 429 \\
Density, $p\left(\mathrm{~kg} / \mathrm{m}^{3}\right)$ & 997.1 & 8933 & 10500 \\
Specific heat capacity, $C_{p}(\mathrm{~J} / \mathrm{kgK})$ & 4179 & 385 & 235 \\
\hline
\end{tabular}

The properties of the fluids are defined as follows (Trisaksri \& Wongwises 2007; Wang \& Mujumdar 2008):

$\mu_{n f}=\frac{\mu_{f}}{(1-\phi)^{2.5}}, \quad \alpha_{n f}=\frac{k_{n f}}{\left(\rho c_{p}\right)_{n f}}, \quad \rho_{n f}=(1-\phi) \rho_{f}+\phi \rho_{s}$,

$\left(\rho C_{p}\right)_{n f}=(1-\phi)\left(\rho C_{p}\right)_{f}+\phi\left(\rho C_{p}\right)_{s}, \quad \frac{k_{n f}}{k_{f}}=\frac{\left(k_{s}+2 k_{f}\right)-2 \phi\left(k_{f}-k_{s}\right)}{\left(k_{s}+2 k_{f}\right)+\phi\left(k_{f}-k_{s}\right)}$ where subscript $n f$ refers to nanofluid, subscript $f$ to base fluid and subscript $s$ to the nanoparticle. While $\mu$ is the dynamic viscosity, $k$ is the thermal conductivity, $p$ is the density, $C_{p}$ is the specific, heat capacity at constant pressure, $\phi$ denotes the nanoparticle volume fraction and $\alpha$ is the thermal diffusivity. 
The similarity variables are adapted from Von Karman transformation (Mustafa et al. 2015; Yin et al. 2017)

$$
\begin{gathered}
\eta=\sqrt{\frac{\Omega}{v_{f \prime}}} z, \quad u=r \Omega F(\eta), \quad v=r \Omega G(\eta), \\
w=\sqrt{v_{f} \Omega} H(\eta), \quad T=T_{\infty}+\left(T_{w}-T_{\infty}\right) \theta(\eta)
\end{gathered}
$$

where $v_{f}$ is the kinematic viscosity of base fluid.

From (2) along with the boundary conditions of (6), when $z \rightarrow \infty$, we obtained $\frac{\partial p}{\partial r}=\rho_{n f} r \Omega^{2}$, indicating an equilibrium of radial pressure gradient and the centrifugal force at the outer flow in Bödewadt flow. Pressure $p$ can be obtained by integrating (4) with respect to $z$, which translates into:

$$
\frac{p}{\rho_{n f}}=-\frac{1}{2} w^{2}+v_{n f} \frac{\partial w}{\partial z}+\frac{1}{2} r^{2} \Omega^{2}
$$

By substituting the variables from (8) into (1)-(6), the following nonlinear system of ordinary differential equations were obtained:

$$
\begin{aligned}
& H^{\prime}+2 F=0, \\
& \frac{1}{(1-\phi)^{2.5}\left(1-\phi+\frac{\phi \rho_{s}}{\rho_{f}}\right)} F^{\prime \prime}-H F^{\prime}-F^{2}+G^{2}-1=0, \\
& \frac{1}{(1-\phi)^{2.5}\left(1-\phi+\frac{\phi \rho_{s}}{\rho_{f}}\right)} G^{\prime \prime}-H G^{\prime}-2 F G=0, \\
& \frac{\frac{k_{n f}}{k_{f}}}{\left(1-\phi+\phi \frac{\left(\rho c_{p}\right)_{s}}{\left(\rho c_{p}\right)}\right.} \frac{1}{P r} \theta^{\prime \prime}-H \theta^{\prime}=0,
\end{aligned}
$$

subject to the boundary conditions

$$
\begin{aligned}
& H(0)=-S, F(0)=\lambda, \quad G(0)=0, \quad \theta(0)=1, \\
& F(\infty)=0, \quad G(\infty)=1, \quad \theta(\infty)=0,
\end{aligned}
$$

where $\operatorname{Pr}=\left(\mu C_{p} / k\right)_{f}$ is the Prandtl number of the base fluid, $\lambda=\frac{c}{\Omega}(>0)$ is the stretching parameter denotes the ratio of stretching rate to the rotation rate and $S=\frac{w_{0}}{\sqrt{v_{f} \Omega}}$ is the constant mass flux parameter where $S>0$ corresponds to wall suction parameter while $S<0$ corresponds to wall injection parameter.

The skin friction coefficient is:

$$
C_{f}=\frac{\sqrt{\tau_{r}^{2}+\tau_{\varphi}^{2}}}{\rho_{f}(r \Omega)^{2}},
$$

where the radial stress, $\tau_{r}$ and tangential stress, $\tau_{\varphi}$ are given by:

$$
\tau_{r}=\left.\mu_{n f} \frac{\partial u}{\partial z}\right|_{z=0}, \quad \tau_{\varphi}=\left.\mu_{n f} \frac{\partial v}{\partial z}\right|_{z=0} .
$$

By using the transformation in (8) and definition in (16), the local skin friction coefficient (15) is translated into:

$$
R e_{r}^{1 / 2} C_{f}=\frac{1}{(1-\phi)^{2.5}} \sqrt{F^{\prime}(0)^{2}+G^{\prime}(0)^{2}}
$$

where $R e_{r}=r^{2} \Omega / v_{f}$ is the local Reynolds number. The local Nusselt number is defined as:

$$
N u_{r}=\frac{r q_{w}}{k_{f}\left(T_{w}-T_{\infty}\right)}
$$

where $q_{w}$ represents the heat flux on the disk which is given by:

$$
q_{w}=-\left.k_{n f} \frac{\partial T}{\partial z}\right|_{z=0} .
$$

By substituting the expressions (8) and (19) into (18), the local Nusselt number becomes:

$$
R e_{r}^{-1 / 2} N u_{r}=-\frac{k_{n f}}{k_{f}} \theta^{\prime}(0)
$$

\section{NUMERICAL METHOD}

Equations (10) to (13) that were subjected to boundary conditions (14), were numerically solved using an implicit finite difference scheme with second-order accuracy which is known as the Keller-box method. Based on the results, the satisfaction of the outer boundary conditions was achieved by considering a sufficiently large boundary layer thickness, ranging from 10 to 20 for all considered values of $S, \lambda, \phi$ and $\operatorname{Pr}$. Besides that, the grid size in $\eta$ and the stopping criterion used for this computation were 0.001 and $1 \times 10^{-7}$, respectively.

\section{RESULTS VALIDATION}

The results yielded in the study were compared with other published results to verify the numerical program and the developed mathematical model. Table 2 indicates the values of the radial shear stress $-F^{\prime}(0)$, tangential shear stress $G^{\prime}(0)$, heat flux $-\theta^{\prime}(0)$ and axial velocity of the fluid at for field condition $-H(\infty)$ for several values of stretching parameter $(\lambda)$ where $\operatorname{Pr}=1, S=0$ and $\phi=0$ (viscous fluid). The results obtained in this study were in good agreement with previous studies by Mustafa et al. (2015), and Turkyilmazoglu (2015). Therefore, we are confident that the present results obtained by the Kellerbox method are acceptable. 
TABLE 2. Comparison of numerical results for some values of when $\phi=S=0$ and $\operatorname{Pr}=1$

\begin{tabular}{llllll}
\hline \multicolumn{1}{c}{$\lambda$} & $-F^{\prime}(0)$ & $G^{\prime}(0)$ & $-\theta^{\prime}(0)$ & $-H(\infty)$ \\
\hline $1 \quad$ Present result & 1.865469 & 0.685170 & 0.543080 & 0.469717 \\
& Mustafa et al. (2015) & 1.865469 & 0.685170 & 0.547181 & 0.469713 \\
& Turkyilmazoglu (2015) & 1.865469 & 0.685170 & 0.543080 & 0.469350 \\
\hline 5 & Present result & 13.46623 & 1.200076 & 1.883582 & 3.215196 \\
& Mustafa et al. (2015) & 13.46623 & 1.200076 & 1.883582 & 3.215196 \\
& Turkyilmazoglu (2015) & 13.46623 & 1.200076 & 1.883582 & 3.215196 \\
\hline 10 & Present result & 37.36036 & 1.678166 & 2.686657 & 4.700371 \\
& Mustafa et al. (2015) & 37.36036 & 1.678166 & 2.6866575 & 4.700370 \\
& Turkyilmazoglu (2015) & 37.36036 & 1.678167 & 2.6866568 & 4.700370 \\
\hline 20 & Present result & 105.153571 & 2.366480 & 3.807548 & 6.702936 \\
& Mustafa et al. (2015) & 105.153500 & 2.366480 & 3.807548 & 6.702935 \\
& Turkyilmazoglu (2015) & 105.153500 & 2.366484 & 3.807547 & 6.702932 \\
\hline
\end{tabular}

\section{RESULTS AND DISCUSSION}

\section{EFFECT OF $S$ ON STATIONARY DISK $(\lambda=0)$}

The effects of suction on radial, tangential and axial velocities, along with the temperature profile, were presented by Mahyuddin et al. (2021). Their study showed that adequate suction was needed to ensure that the similarity solution for the thermal energy problem was physically realistic. Hence, we further investigated the problem by plotting the local skin friction coefficient, $R e_{r}^{1 / 2} C_{f}(17)$, and local Nusselt number, $R e_{r}^{-1 / 2} N u_{r}(20)$, against the constant mass flux parameter $S$ in Figures 2 and 3 , respectively, for $\phi=0,0.01,0.05$, and 0.1 , when $\lambda$ $=0$ and $\operatorname{Pr}=6.2$. Based on these figures, both $\operatorname{Re}_{r}^{1 / 2} C_{f}$ and $R e_{r}^{-1 / 2} N u_{r}$ increased as $S$ increased. For a fixed suction parameter, nanofluids $(\phi=0.01,0.05,0.1)$ can enhance the wall shear stress compared to viscous fluid $(\phi=0)$.

On the other hand, Figure 3 indicates the existence of temperature solutions at the region $S \geq S_{c}$, where $S_{c}=$ $0.85,0.83,0.78$ and 0.74 for $\phi=0,0.01,0.05$ and 0.1 , respectively. There is no temperature solution for the case of injection. Our critical value $S_{c}=0.85$ for $\phi=$ 0 was in favorable agreement with the value reported by Rahman and Andersson (2017), $S_{c}=0.85$. In short, the local Nusselt number decreases as $\phi$ increases for a fixed suction parameter. However, it contradicts the general expectation that nanofluid helps enhance the heat transfer rate. The additional investigation also showed that for small $S$, the local Nusselt number initially increases to a maximum value before decreasing with an increment in nanoparticle volume fraction. The same observation was also noted in the problem of Von Karman flow in nanofluids studied by Mustafa and Khan (2017). Based on Table 3, for $S=0.85$ and 0.86 , the heat transfer rate increased when $\phi \leq 0.02$ ( $2 \%$ of nanoparticles). Meanwhile, for $S=0.87$, the percent of nanoparticles should be no more than approximately $1 \%(\phi=0.01)$, so that the process of heat transfer is maximized. Nanofluids diminished the heat transfer rate when $S>0.88$.

\section{EFFECT OF SON STRETCHING DISK $(\lambda>0)$}

Numerical results were obtained for the combined effects of stretching disk with the presence of suction and injection. Table 4 depicts the comparison between the values $F^{\prime}(0), G^{\prime}(0), \theta^{\prime}(0)$ and $H(\infty)$ for the two types of nanoparticles used in this study, Ag and $\mathrm{Cu}$. During the computation, the values of the suction parameter, $S=$ $2,1,0,-1,-2$ and -3 were considered with the change of nanoparticles volume fraction, $\phi=0.01,0.05$ and 0.1 , while the stretching rate and Prandtl number were fixed constants, $\lambda=3$ and $\operatorname{Pr}=6.2$, respectively. Based on the observation, increasing the mass flux parameter 


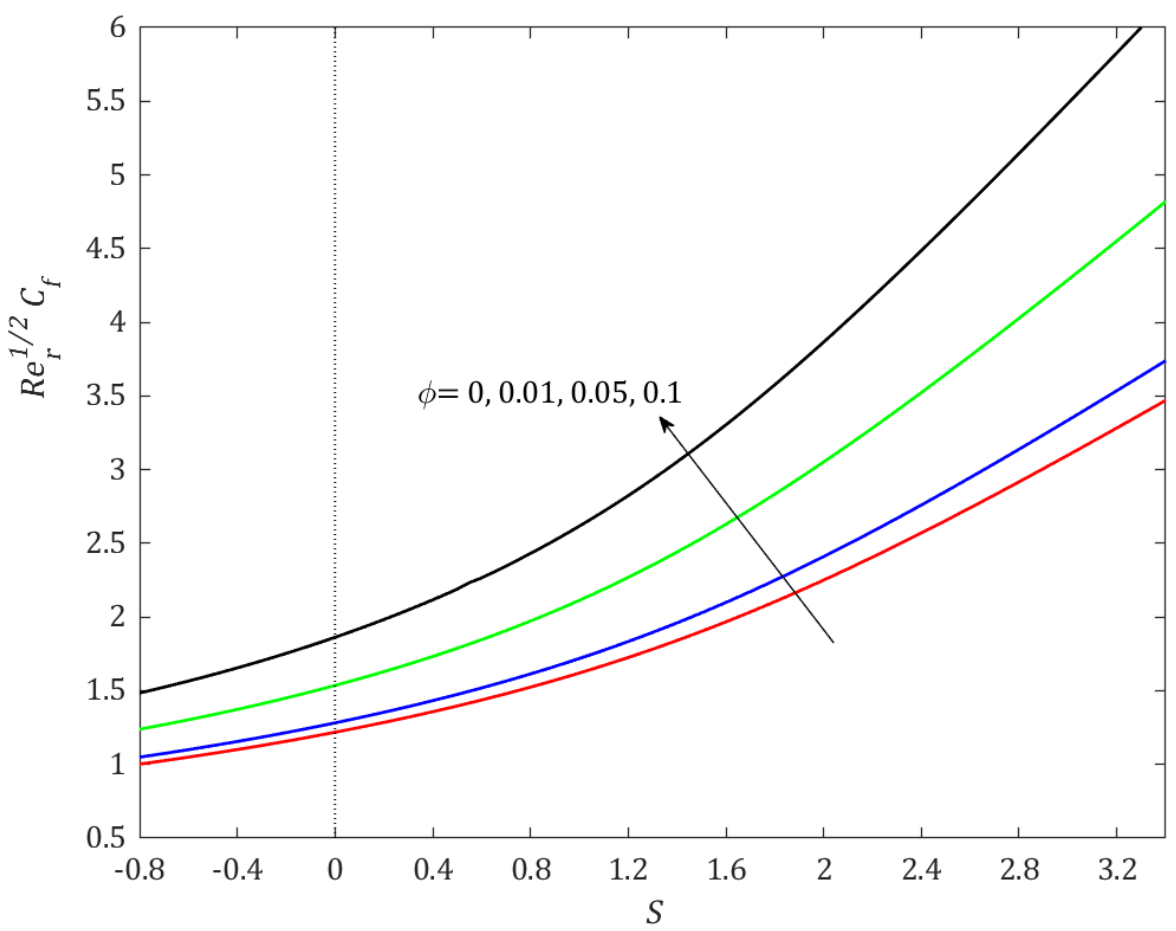

FIGURE 2. Variation of $\operatorname{Re}_{r}^{1 / 2} C_{f}$ against $S$ for values of $\phi$ stated in the graph when $\lambda=0$ (Cu nanoparticles)

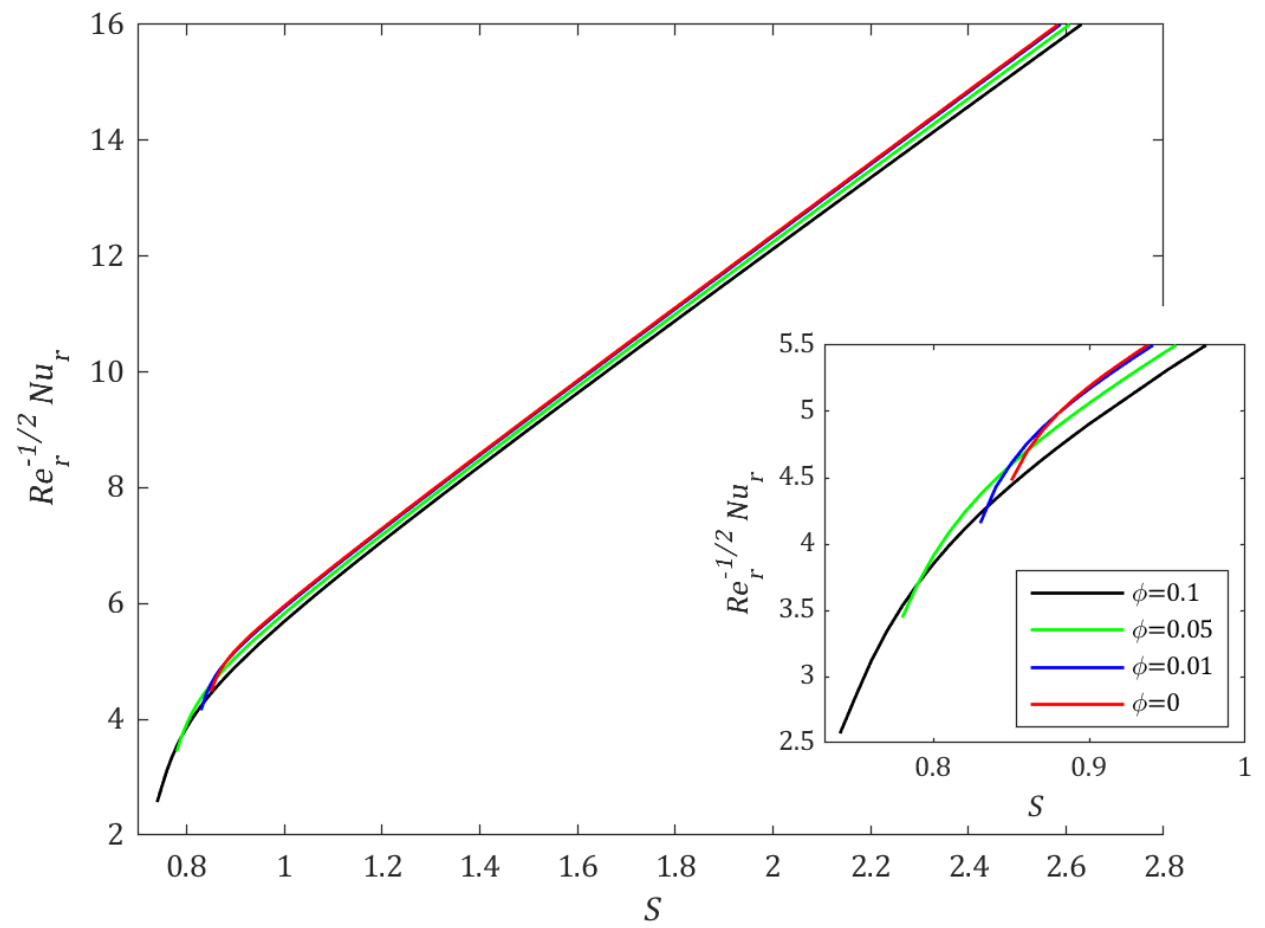

FIGURE 3. Variation of $R e_{r}^{-1 / 2} N u_{r}$ against $S$ for values of $\phi$ stated in the graph when $\lambda=0$ and $\operatorname{Pr}=6.2$ (Cu nanoparticles) 
from negative values to positive values, can increase the magnitude of radial shear stress $F^{\prime}(0)$, tangential shear stress $G^{\prime}(0)$ and heat flux $\theta^{\prime}(0)$. A larger volume fraction of nanoparticles can significantly affect the heat flux $\theta^{\prime}$ (0), for which the magnitude decreased as the nanoparticle volume fraction was increased. This observation was more apparent for the large suction parameter. However, for large injection parameter, the opposite trend is observed. Meanwhile, Table 4 indicated that the variation between the two types of nanoparticles was minimal. Hence, since the difference is minimal, the use of $\mathrm{Cu}$ as a nanoparticle is more promising compared to Ag because the corrosionresistant $\mathrm{Cu}$ possesses high thermal conductivity and is economical.

TABLE 3. Values of $R e_{r}^{-1 / 2} N u_{r}$ for some values of $\phi$ and $S$ when $\lambda=0$ and $\operatorname{Pr}=6.2$ (Cu nanoparticles)

\begin{tabular}{cccccc}
\hline \multicolumn{5}{c}{$R e_{r}^{-1 / 2} N u_{r}$} \\
\hline$\phi$ & $S=0.85$ & $S=0.86$ & $S=0.87$ & $S=0.88$ & $S=0.89$ \\
\hline 0.00 & 4.509683 & 4.709179 & 4.862021 & 4.986626 & 5.093809 \\
0.01 & 4.619086 & 4.760238 & 4.879919 & 4.985595 & 5.081861 \\
0.02 & 4.644236 & 4.763824 & 4.870748 & 4.968827 & 5.060553 \\
0.03 & 4.640253 & 4.750097 & 4.851088 & 4.945563 & 5.035131 \\
0.04 & 4.623642 & 4.728458 & 4.826365 & 4.918988 & 5.007491 \\
0.05 & 4.600501 & 4.702525 & 4.798753 & 4.890422 & 4.978444 \\
0.08 & 4.512298 & 4.611464 & 4.706297 & 4.797542 & 4.885780 \\
0.10 & 4.444692 & 4.543942 & 4.639230 & 4.731170 & 4.820256 \\
\hline
\end{tabular}

Figures 4 to 7 illustrate the effects of suction and injection on the Bödewadt boundary layer flow with a constant volume fraction of nanoparticles $(\phi=0.1)$ and stretching parameter $(\lambda=3)$ while the Prandtl number was fixed at 6.2. Based on Figure 4, a negative region of radial velocity for the case of injection indicates that the flow is radially inward near the surface disk. With the increasing suction, the tangential velocity in Figure 5 increased, subsequently causing an increase in centrifugal force. Consequently, the flow was radially outward, resulting in a reduction of the axial flow $(H$ $<0$ ) as in Figure 6. Whereas, Figure 7 presents the temperature profiles for different values of mass flux parameter. In the previous section, no results were obtained for $S<S_{c}$ when $\lambda=0$. However, in this section, the presence of radially stretching disk $(\lambda=3)$ suppressed the oscillatory behavior of flow, allowing similarity solutions to be obtained for all values of $S$ that considered. A similar role was observed for the suction parameter too, where the oscillations were damped in the presence of suction. The trends in Figures 4 to 7 indicated that the intensification of suction for a stretching disk causes the boundary layer thickness to drastically reduce as suction increased. Thus, the velocity and temperature profiles reached asymptotic velocity at a shorter distance. In contrast, the presence of injection magnified the oscillations, evidence from the overshoot in both the radial and tangential velocities. Both the momentum and thermal boundary layer thicknesses increases as injection parameter is increased.

Figure 8 depicts the variation of the local skin friction coefficient $\left(R e_{r}^{1 / 2} C_{f}\right)$ against the mass flux parameter $(S)$ for some values of nanoparticle volume fraction and stretching parameter. The curve pattern for local skin friction coefficient in Figure 8 (with $\lambda=1,3,5$ ) was similar to Figure 1 (with $\lambda=0$ ), i.e. $R e_{r}{ }^{1 / 2} C_{f}$ increased as $S$ increased. Moreover, the increased volume fraction of nanoparticles and the stretching rate can also increase skin friction. According to Figure 9, the increment in local Nusselt number $\left(\operatorname{Re}_{r}^{-1 / 2} N u_{r}\right)$ with increased $S$ and $\lambda$, indicated the enhancement in heat transfer rate. Although the heat transfer rate was greater for larger $\phi$, the trend was reversed when $S$ increased. Therefore, for positive and large $S$, smaller volume fraction of nanoparticle yielded a slightly larger $R e_{r}^{-1 / 2} N u_{r}$ than the larger volume fraction of nanoparticle. For the case of $\lambda=1$, the temperature solutions exist at the region $S \geq S_{c}$, where $S_{c}=-0.34$ and -0.29 for $\phi=0.01$ and 0.1 , respectively. Its profile is similar to those shown in Figure 3 for the case $\lambda=0$. The critical value of $S_{c}$ increases when increasing the stretching rate, i.e. $S_{c}=$ -4.11 and -3.58 for $\lambda=3 ; S_{c}=-10.74$ and -9.33 for $\lambda=$ 5 ; where the former is for $\phi=0.01$ and the latter is for $\phi$ $=0.1$. It can be seen from Figure 9 that the local Nusselt number approaches zero (no heat transfer occurs) for large injection parameter. 
TABLE 4. Comparison between silver $(\mathrm{Ag})$ and copper $(\mathrm{Cu})$ in the presence of suction/injection and nanoparticles volume fraction when $\lambda=3$ and $\operatorname{Pr}=6.2$

\begin{tabular}{|c|c|c|c|c|c|c|}
\hline \multicolumn{7}{|c|}{$\mathrm{Ag}$} \\
\hline$S$ & & $\phi$ & $-F^{\prime}(0)$ & $G^{\prime}(0)$ & $-\theta^{\prime \prime}(0)$ & $-H(\infty)$ \\
\hline \multirow{3}{*}{\multicolumn{2}{|c|}{2}} & 0.01 & 10.798987 & 2.480358 & 13.905432 & 3.547571 \\
\hline & & 0.05 & 12.436693 & 2.937946 & 12.292465 & 3.352139 \\
\hline & & 0.10 & 13.834538 & 3.336897 & 10.589373 & 3.221061 \\
\hline \multirow{3}{*}{\multicolumn{2}{|c|}{1}} & 0.01 & 8.627136 & 1.655237 & 8.725671 & 2.859821 \\
\hline & & 0.05 & 9.744711 & 1.911786 & 7.785368 & 2.654970 \\
\hline & & 0.10 & 10.677874 & 2.131267 & 6.786315 & 2.516310 \\
\hline \multirow{3}{*}{\multicolumn{2}{|c|}{0}} & 0.01 & 6.757106 & 0.985367 & 4.273032 & 2.229143 \\
\hline & & 0.05 & 7.451168 & 1.086580 & 3.906803 & 2.021503 \\
\hline & & 0.10 & 8.009573 & 1.168011 & 3.509603 & 1.880569 \\
\hline \multirow{3}{*}{\multicolumn{2}{|c|}{-1}} & 0.01 & 5.216402 & 0.508622 & 1.264024 & 1.642309 \\
\hline & & 0.05 & 5.598553 & 0.519279 & 1.239010 & 1.436388 \\
\hline & & 0.10 & 5.888237 & 0.523965 & 1.208409 & 1.296809 \\
\hline \multirow{3}{*}{\multicolumn{2}{|c|}{-2}} & 0.01 & 4.005748 & 0.222078 & 0.143003 & 1.086221 \\
\hline & & 0.05 & 4.185982 & 0.201958 & 0.167306 & 0.884386 \\
\hline & & 0.10 & 4.310570 & 0.184836 & 0.199481 & 0.748064 \\
\hline \multirow{3}{*}{\multicolumn{2}{|c|}{-3}} & 0.01 & 3.099728 & 0.080536 & 0.003919 & 0.556447 \\
\hline & & 0.05 & 3.170043 & 0.062457 & 0.006344 & 0.361595 \\
\hline & & 0.10 & 3.212534 & 0.049883 & 0.010557 & 0.231014 \\
\hline \multicolumn{7}{|c|}{$\mathrm{Cu}$} \\
\hline \multirow{2}{*}{\multicolumn{2}{|c|}{$S$}} & $\phi$ & $-F^{\prime}(0)$ & $G^{\prime}(0)$ & $-\theta^{\prime}(0)$ & $-H(\infty)$ \\
\hline & & 0.01 & 10.688273 & 2.449856 & 13.937964 & 3.562884 \\
\hline \multirow{3}{*}{\multicolumn{2}{|c|}{2}} & 0.05 & 11.951193 & 2.801107 & 12.438394 & 3.404634 \\
\hline & & 0.10 & 13.002190 & 3.098488 & 10.845651 & 3.295809 \\
\hline & & 0.01 & 8.550534 & 1.637919 & 8.745873 & 2.875793 \\
\hline \multirow{3}{*}{\multicolumn{2}{|c|}{1}} & 0.05 & 9.416310 & 1.835661 & 7.876365 & 2.710195 \\
\hline & & 0.10 & 10.124357 & 2.000525 & 6.947326 & 2.595524 \\
\hline & & 0.01 & 6.708455 & 0.978273 & 4.282608 & 2.245309 \\
\hline \multirow{3}{*}{\multicolumn{2}{|c|}{0}} & 0.05 & 7.250189 & 1.057272 & 3.950165 & 2.077540 \\
\hline & & 0.10 & 7.680564 & 1.120032 & 3.587596 & 1.961126 \\
\hline & & 0.01 & 5.188671 & 0.507660 & 1.266545 & 1.658353 \\
\hline \multirow{2}{*}{\multicolumn{2}{|c|}{-1}} & 0.05 & 5.490452 & 0.516766 & 1.250322 & 1.491931 \\
\hline & & 0.10 & 5.719439 & 0.521603 & 1.229545 & 1.376571 \\
\hline \multirow{3}{*}{\multicolumn{2}{|c|}{-2}} & 0.01 & 3.991977 & 0.223412 & 0.143174 & 1.101976 \\
\hline & & 0.05 & 4.136815 & 0.207960 & 0.167876 & 0.938752 \\
\hline & & 0.10 & 4.239247 & 0.194986 & 0.200553 & 0.825909 \\
\hline \multirow{3}{*}{\multicolumn{2}{|c|}{-3}} & 0.01 & 3.093951 & 0.081896 & 0.003917 & 0.571719 \\
\hline & & 0.05 & 3.151863 & 0.067425 & 0.006318 & 0.413921 \\
\hline & & 0.10 & 3.188849 & 0.057070 & 0.010659 & 0.305464 \\
\hline
\end{tabular}




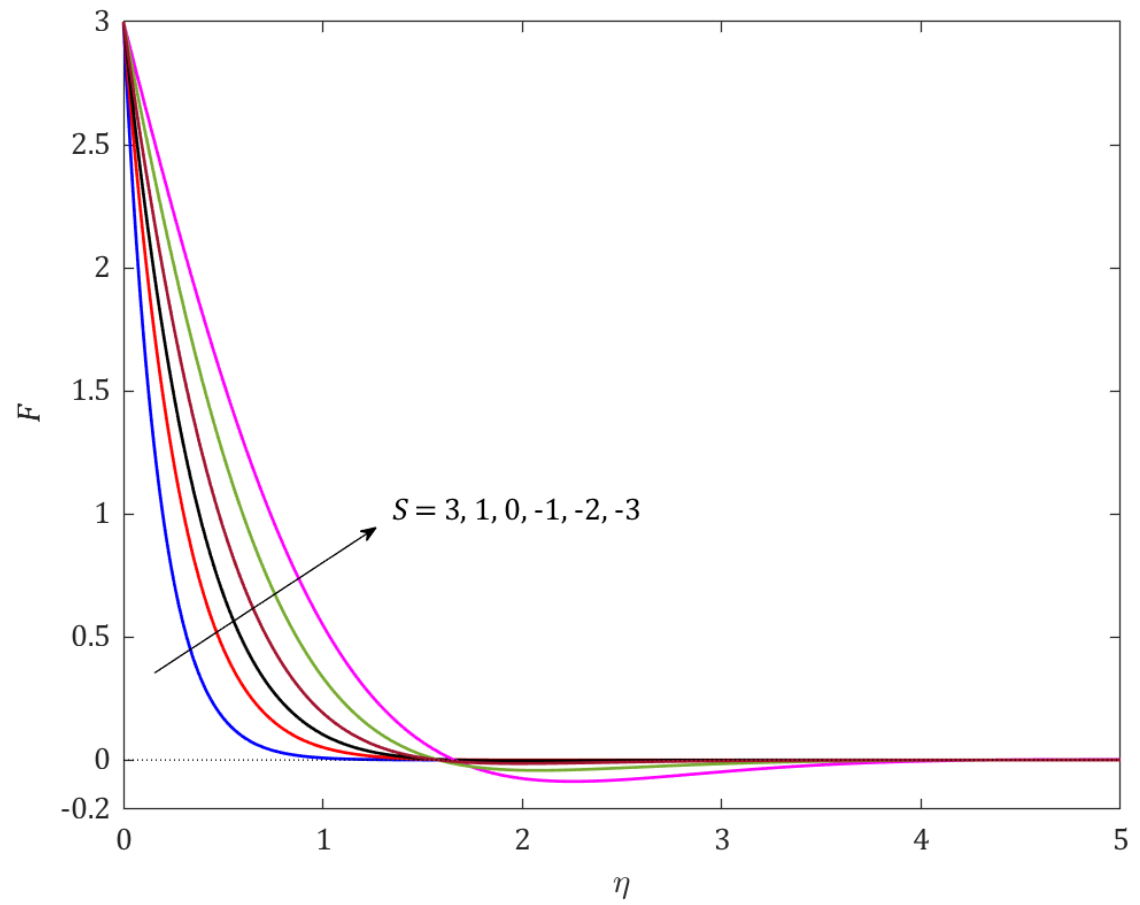

FIGURE 4. Effect of mass flux parameter on the radial velocity component when $\operatorname{Pr}=6.2, \phi=0.1$ and $\lambda=1$ (Cu nanoparticles)

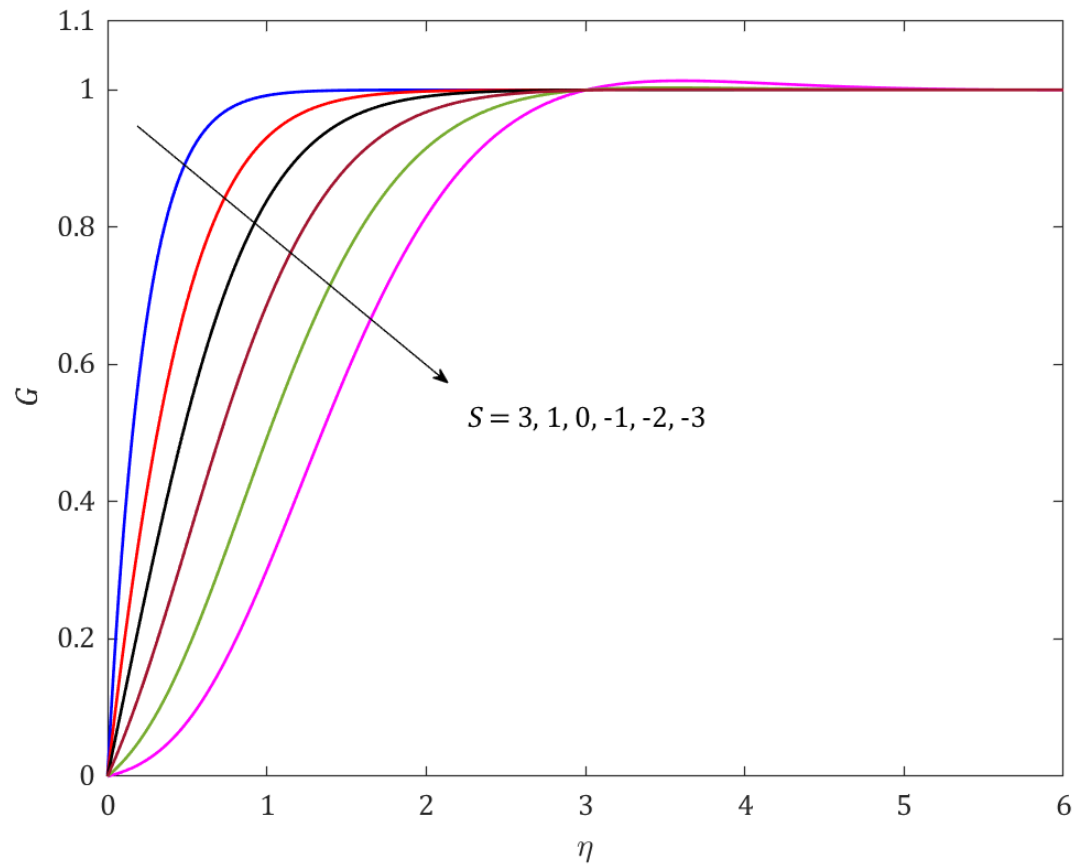

FIGURE 5. Effect of mass flux parameter on the tangential velocity component when $\operatorname{Pr}=6.2, \phi=0.1$ and $\lambda=1$ (Cu nanoparticles) 


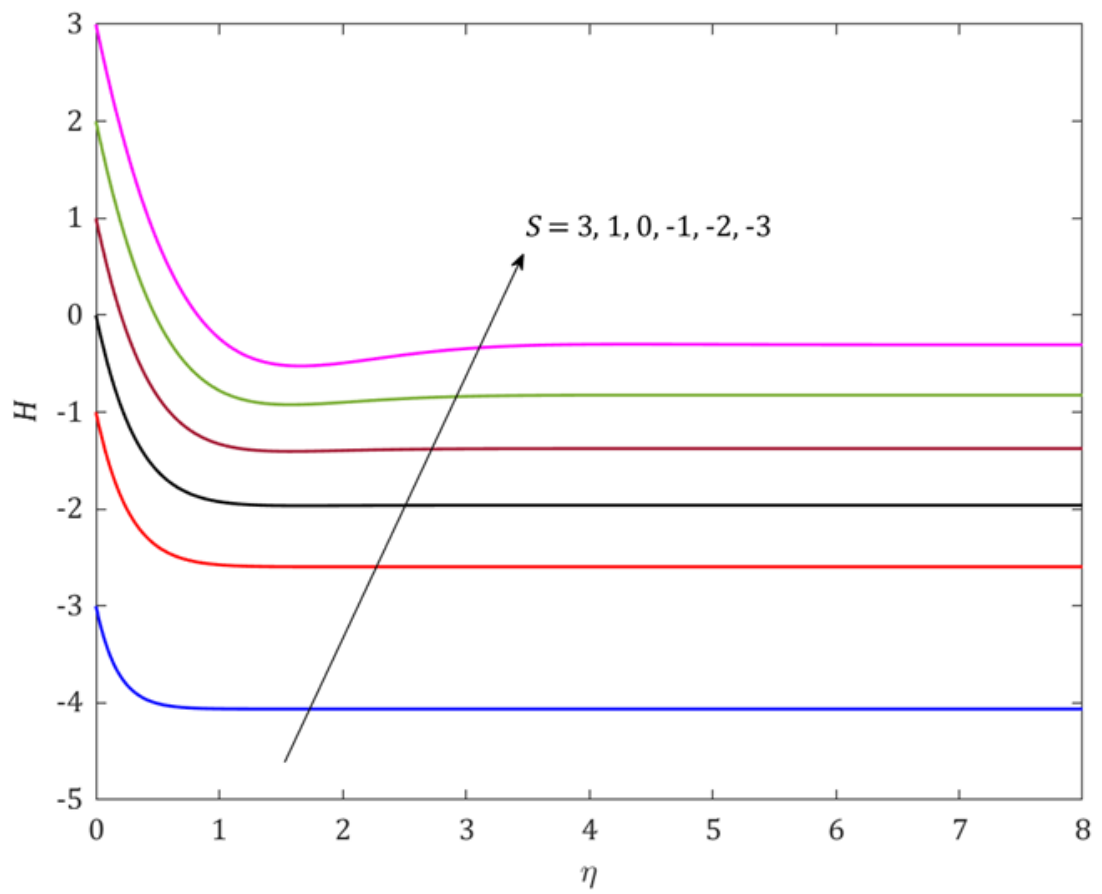

FIGURE 6. Effect of mass flux parameter on the axial velocity component when $\mathrm{Pr}$ $=6.2, \phi=0.1$ and $\lambda=1$ (Cu nanoparticles)

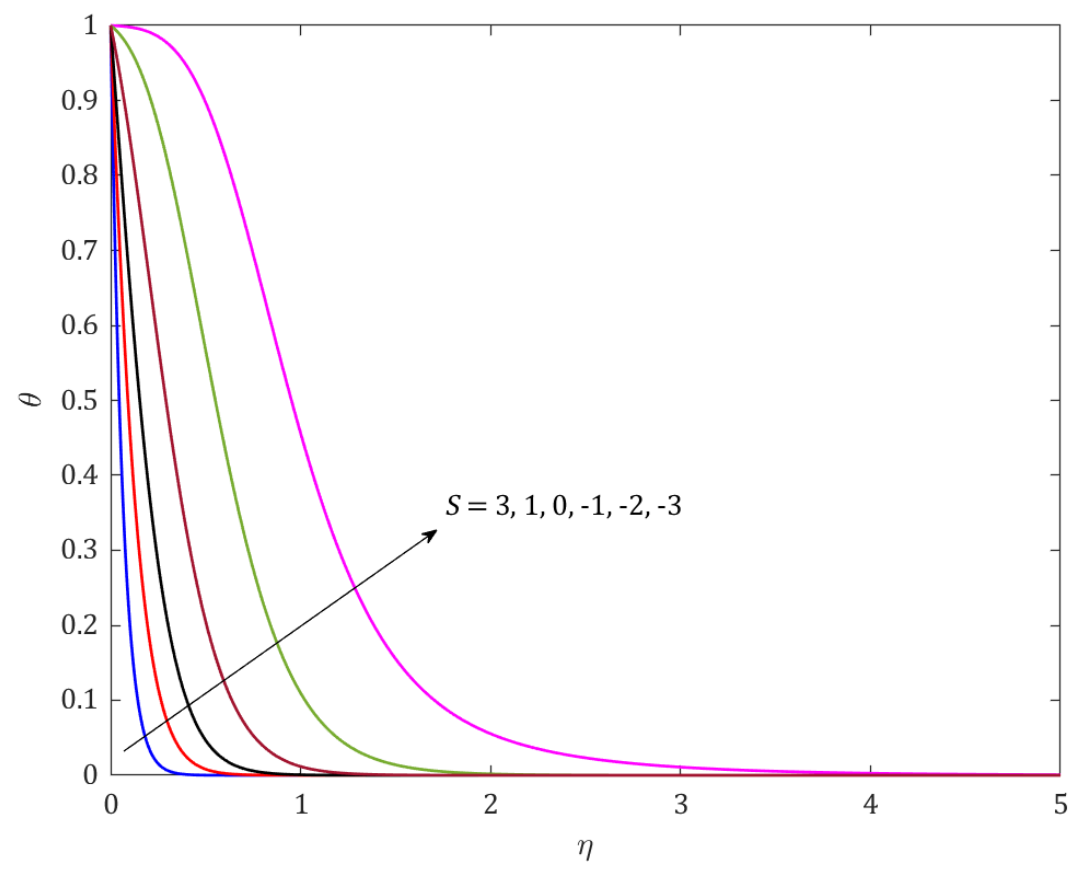

FIGURE 7. Effect of mass flux parameter on the temperature profile when $\operatorname{Pr}=6.2$, $\phi=0.1$ and $\lambda=1$ (Cu nanoparticles) 


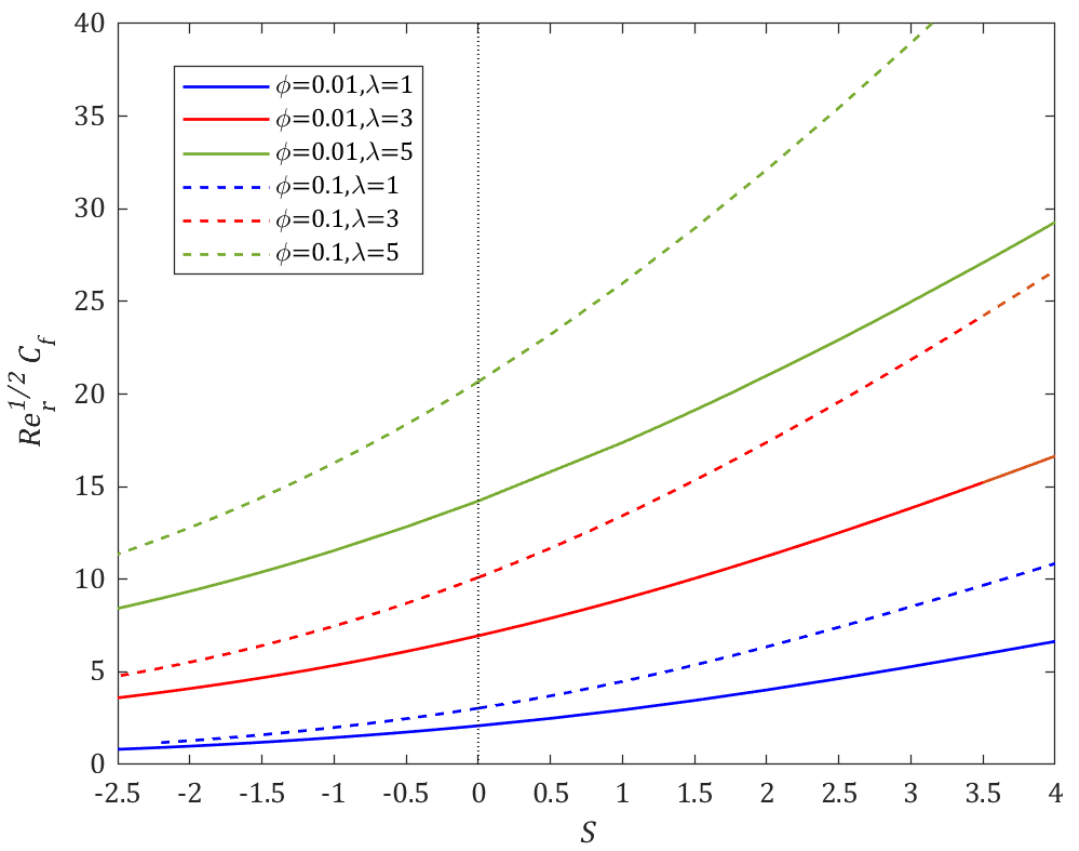

FIGURE 8. Variation of $\operatorname{Re}_{r}^{1 / 2} C_{f}$ against $S$ for values of $\phi$ and $\lambda$ stated in the graph (Cu nanoparticles)

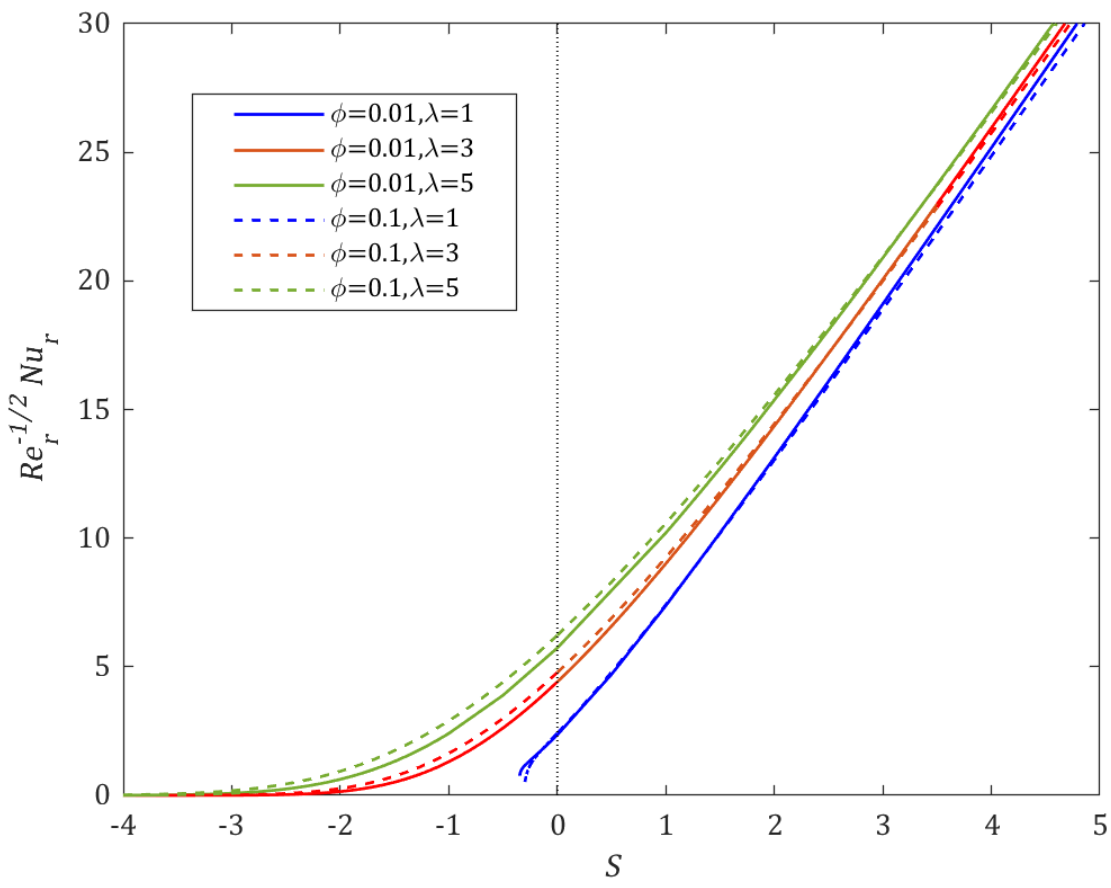

FIGURE 9. Variation of $R e_{r}^{-1 / 2} N u_{r}$ against $S$ for values of $\phi$ and $\lambda$ stated in the graph when $\operatorname{Pr}=6.2$ (Cu nanoparticles) 


\section{CONCLUSION}

The numerical solutions of Bödewadt boundary layer flow and the occurrence of heat transfer in nanofluid were presented in this study. The effects of suction/ injection along with the combined effects of suction/ injection and stretching disk on the flow were also investigated. The summary of the results of the present study is listed herewith: 1 . In the absence of radially stretching disk, nanofluid can enhance the wall shear stress but diminishes the heat transfer rate. It can only enhance the heat transfer when the suction parameter and nanoparticle volume fraction are sufficiently small. 2. The imposition of sufficient suction to the Bödewadt flow (without other effects such as a radially stretching disk or slip condition) is required to ensure the presence of a similarity solution for the heat transfer problem. 3. The presence of suction and stretching of the disk suppressed the oscillatory behavior of Bödewadt flow. Injection, on the other hand, amplified the oscillatory behavior. 4. For a fixed stretching parameter, the thickness of the boundary layer decreased with an increased suction value, allowing the velocity and temperature profiles to reach their asymptotic conditions at a shorter distance. The opposite trend is observed for the case of injection. 5. The local skin friction coefficient and local Nusselt number increased linearly with increasing mass flux parameter. 6 . Increments in the volume fraction of nanoparticles and stretching rate can increase the skin friction coefficient and heat transfer rate. However, for large suction, the heat transfer rate is greater for small nanoparticle volume fraction. 7. Heat transfer does not occur for large injection parameter.

\section{ACKNOWLEDGEMENTS}

The authors would like to acknowledge the financial support received from the Ministry of Higher Education, Malaysia for Fundamental Research Grant Scheme with Project Code: FRGS/1/2018/STG06/USM/02/5.

\section{REFERENCES}

Batchelor, G.K. 1951. Note on a class of solutions of the NavierStokes equations representing steady rotationally-symmetric flow. The Quarterly Journal of Mechanics and Applied Mathematics 4(1): 29-41.

Cengel, Y.A. 2004. Heat Transfer: A Practical Approach. 2nd ed. New York: McGraw-Hill.

Faller, A.J. 1991. Instability and transition of disturbed flow over a rotating disk. Journal of Fluid Mechanics 230: 245-269.

Fernandez-Feria, R. 2002. Stability analysis of boundary layer flow due to the presence of a small hole on a surface. Physical Review E 65(3): 036307.
Joshi, V.K., Ram, P., Sharma, R.K. \& Tripathi, D. 2017. Porosity effect on the boundary layer Bodewadt flow of a magnetic nanofluid in the presence of geothermal viscosity. The European Physical Journal Plus 132(6): 254.

Khan, J.A., Mustafa, M., Hayat, T. \& Alzahrani, F. 2017. Numerical study for Bödewadt flow of water based nanofluid over a deformable disk: Buongiorno model. Indian Journal of Physics 91(5): 527-533.

Lingwood, R.J. \& Alfredsson, P.H. 2000. Experimental study of the stability of the Bödewadt layer. In Laminar-Turbulent Transition. IUTAM Symposia (International Union of Theoretical and Applied Mechanics), edited by Fasel, H.F. \& Saric, W.S. Berlin, Heidelberg: Springer. pp. 553-558.

Lopez, J.M. \& Weidman, P.D. 1996. Stability of stationary endwall boundary layers during spin-down. Journal of Fluid Mechanics 326: 373-398.

MacKerrell, S.O. 2005. Stability of Bödewadt flow. Philosophical Transactions of the Royal Society A: Mathematical, Physical and Engineering Sciences 363(1830): 1181-1187.

Mahyuddin, A.A., Lok, Y.Y. \& Ahmad, S. 2021. Bödewadt flow and heat transfer in nanofluid over a stagnant disk with suction. In Proceedings of the International Conference on Mathematical Science and Technology 2020 (MathTech 2020), AIP Conference Proceedings. AIP Publishing. No. 2423: 020012.

Mustafa, M. \& Khan, J.A. 2017. Numerical study of partial slip effects on MHD flow of nanofluids near a convectively heated stretchable rotating disk. Journal of Molecular Liquids 234: 287-295.

Mustafa, M., Pop, I., Naganthran, K. \& Nazar, R. 2018. Entropy generation analysis for radiative heat transfer to Bödewadt slip flow subject to strong wall suction. European Journal of Mechanics - B/Fluids 72: 179-188.

Mustafa, M., Khan, J.A., Hayat, T. \& Alsaedi, A. 2015. On Bödewadt flow and heat transfer of nanofluids over a stretching stationary disk. Journal of Molecular Liquids 211: 119-125.

Rafiq, T. \& Hashmi, M.M. 2019. Bödewadt flow over a permeable disk with homogeneous-heterogeneous reactions: A numerical study. Applied Sciences 9(19): 4046.

Rafiq, T., Mustafa, M. \& Farooq, M.A. 2019. Numerical assessment of Bödewadt flow and heat transfer over a permeable disk with variable fluid properties. Physica A: Statistical Mechanics and its Applications 534: 122138.

Rahman, M. \& Andersson, H.I. 2018. Revolving flow of a fluidparticle suspension with suction. Alexandria Engineering Journal 57(4): 2567-2572.

Rahman, M. \& Andersson, H.I. 2017. On heat transfer in Bödewadt flow. International Journal of Heat and Mass Transfer 112: 1057-1061.

Sahoo, B. 2011. Effects of slip on steady Bödewadt flow and heat transfer of an electrically conducting non-Newtonian fluid. Communications in Nonlinear Science and Numerical Simulation 16(11): 4284-4295.

Sahoo, B. \& Shevchuk I.V. 2019. Heat transfer due to revolving flow of Reiner-Rivlin fluid over a stretchable surface. Thermal Science and Engineering Progress 10: 327-336. 
Sahoo, B. \& Poncet, S. 2012. Effects of slip on steady Bödewadt flow of a non-Newtonian fluid. Communications in Nonlinear Science and Numerical Simulation 17(11): 4181-4191.

Sahoo, B., Poncet, S. \& Labropulu, F. 2015. Suction/injection effects on the swirling flow of a Reiner-Rivlin fluid near a rough surface. Journal of Fluids 2015: 253504.

Sahoo, B., Abbasbandy, S. \& Poncet, S. 2014. A brief note on the computation of the Bödewadt flow with Navier slip boundary conditions. Computers \& Fluids 90: 133-137.

Sahoo, B., Van Gorder, R.A. \& Andersson, H.I. 2012. Steady revolving flow and heat transfer of a non-Newtonian ReinerRivlin fluid. International Communications in Heat and Mass Transfer 39(3): 336-342.

Savaş, Ö. 1987. Stability of Bödewadt flow. Journal of Fluid Mechanics 183: 77-94.

Schlichting, H. 1979. Boundary-Layer Theory. 7th ed. New York: McGraw-Hill.

Trisaksri, V. \& Wongwises, S. 2007. Critical review of heat transfer characteristics of nanofluids. Renewable and Sustainable Energy Reviews 11(3): 512-523.

Turkyilmazoglu, M. 2015. Bödewadt flow and heat transfer over a stretching stationary disk. International Journal of Mechanical Sciences 90: 246-250.
Turner, M.R. \& Weidman, P. 2017. Stability of a radially stretching disk beneath a uniformly rotating fluid. Physical Review Fluids 2(7): 073904

Wang, X.Q. \& Mujumdar, A.S. 2008. A review on nanofluids part II: Experiments and applications. Brazilian Journal of Chemical Engineering 25(4): 631-648.

Yin, C., Zheng, L., Zhang, C. \& Zhang, X. 2017. Flow and heat transfer of nanofluids over a rotating disk with uniform stretching rate in the radial direction. Propulsion and Power Research 6(1): 25-30.

Anis Anisah Mahyuddin \& Lok Yian Yian*

Mathematics Section, School of Distance Education

Universiti Sains Malaysia

11800 USM, Penang

Malaysia

Syakila Ahmad

School of Mathematical Sciences

Universiti Sains Malaysia

11800 USM, Penang

Malaysia

*Corresponding author; email: lokyy@usm.my

Received: 10 March 2021

Accepted: 2 June 2021 